\title{
Accounting
}

\section{Timeliness of corporate annual financial reporting in Indonesian banking industry}

\author{
Wahyu Murtia*
}

${ }^{a}$ Faculty of Economy, University Borobudur Jakarta, Indonesia

\begin{tabular}{l}
\hline C H R O N I C L E \\
\hline Article history: \\
Received: December 3, 2021 \\
Received in revised format: \\
December 302020 \\
Accepted: January 6, 2021 \\
Available online: \\
January 6, 2021 \\
\hline Keywords: \\
Debt Equity Ratio \\
Firm Size \\
Liquidity \\
Timelines Financial Report
\end{tabular}

\section{Introduction}

Globally, the banking sector plays an important role for the economic growth of every country. The performance of the banking sector around the world has raised concerns among professionals, especially in the banking sector (Pinto \& Joseph, 2017). The financial performance of the banking sector globally can be seen in the capital markets of each country. One of the important sources of information in the investment business in the capital market is the financial reports that are provided publicly traded companies. Zandi (2019) defines information as evidence that has the potential to influence individual decisions. Information must have seven main characteristics that are relevant, reliable, complete, timely, understandable, verifiable and accessible (Viet et al., 2018). In order to keep up with the dynamic business world, up to date information is needed at all times. New information is able to provide an accurate and relevant picture of the current state of a business. Information is said to be relevant if that information has the ability to make a difference in a decision. Information can be presented in the form of financial statements (Krishnamoorthy et al., 2002). Financial reports are very useful information for business people in the capital market (Abernathy et al., 2018). Financial reports are presented and prepared by the management of a companies to internal and external parties and contain all business activities of a single business entity which is one of management's accountability and communication tools to those who

* Corresponding author.

E-mail address: wahyu_murti@borobudur.ac.id (W. Murti)

(C) 2021 by the authors; licensee Growing Science, Canada doi: 10.5267/j.ac.2021.1.003 
need it (Kemal, 2019). For companies that have gone public, several studies have been conducted by researchers and academics before investigating the factors that influence the timeliness of corporate financial reporting using several variables. According to Du and $\mathrm{Wu}$ (2018), ownership structure and profitability do not have significant effects on the accuracy of financial reports, while leverage and liquidity have significant effects on the timeliness of financial reporting. Nelson et al. (2019) conducted a research on companies listed on the Indonesian Stock Exchange during the period 2014-2019. The results showed that the profitability and ownership structure had significant effects on the timeliness of the company's financial reporting, while the quality of auditors and auditor turnover had no effect on the timeliness of financial reporting of manufacturing companies listed on the Indonesia Stock Exchange (Murti, 2017a,b).

The Timelines Financial Report theory states that the timeliness of financial reporting is the period of time to announce audited annual financial reports to the public from the closing date of the company's books (31 December) to the date of submission to the Capital Market (Zandi, 2019). Timely financial reports will be more useful and the availability of a quick and relevant information helps making better decisions (Sufiyati, 2017). The timeliness between the date of the company's financial statements and the date when the financial information is announced to the public is related to the quality of the financial information reported (Du \& Wu, 2018). Kemal (2019) stated that information cannot be relevant if it is not timely, that is, it must be made available to decision makers before losing its capacity to influence decisions. Timeliness does not guarantee its relevance, but relevance is not possible without timeliness. Therefore, timeliness is an important limitation on the publication of financial statements. Zandi (2019) reported that leverage, ownership structure, and profitability may not have a significant effect on the accuracy of financial statements while leverage and liquidity had a significant effect on the timeliness of financial reporting.

\section{Literature Review}

The theory used in this paper considers Liquidity, debt to equity ratio and Firm Size as independent variable while Timelines is the dependent variable.

\subsection{Timelines}

Timelines of financial reporting is the period of time to announce audited annual financial statements to the public from the closing date of the company's books (31 December) to the date of submission to the Stock Exchange (Sufiyati, 2017). Timely financial reports will be more useful than untimely. Once the relevant information is available more quickly, it is able to increase its capacity to influence decisions, and the lack of timeliness can reduce information from its usefulness (Abernathy et al., 2018). Timeliness of reporting financial information is needed by users of financial statement information. Financial reports are an important element needed by information users to make investment and credit decisions (Abernathy et al., 2018). The rise of issuers who are late in reporting financial statements is a serious concern for the Stock Exchange (Abernathy et al., 2018). When companies postpone their financial reporting to the public, the information cannot be used for decision making. Being on time is one of the characteristics that must be present in information (Kemal, 2019). Timelines is influenced by several factors, including liquidity, Debt to Equity Ratio, and firm Size.

\section{$\mathrm{H}_{1}$ : Liquidity, Firm Size, Debt to Equity Ratio simultaneously have significant effects on the Timelines Financial Report on banking companies listed on the Indonesia Stock Exchange for the period 2014-2019.}

\subsection{Liquidity}

The liquidity ratio is a ratio that measures the company's ability to pay short-term debt obligations. Liquidity is measured by Current Ratio, Cash Ratio, Quick Ratio and Working Capital to total assets. In this study, the current liquidity ratio is used by outsiders which has a great power in influencing companies in assessing the ability of the banking sector to pay short-term debt. Arowoshegbe et al. (2017) found that liquidity has a significant effect on the timeliness of financial report submission. With external supervision, management is required to show good performance by providing information on banking liquidity, financial position, banking performance and changes in financial position.

\section{$\mathrm{H}_{2}$ : Partial liquidity has a significant effect on the Timelines Financial Report on banking companies listed on the Indonesia Stock Exchange for the period 2014-2019.}

\subsection{Debt to Equity Ratio}

Debt to equity ratio is also known as financial leverage ratio. According to Chukwu and Nwabochi (2019), the leverage ratio measures the level of company assets that have been financed by the use of debt. The high debt to equity ratio reflects the company's high risk. This high risk indicates the possibility that the company cannot pay off its obligations or debts in the form of principal or interest (Abernathy et al., 2018). The high debt to equity ratio reflects the high financial risk of the company. 
Management tends to delay the submission of bad news financial reports, since the time available is used to reduce the debt-toequity ratio to the lowest level. Research on the debt-to-equity ratio on timeliness was carried out by Sufiyati (2017). In research on debt-to-equity ratio to punctuality, Al-Juaidi and Al-Afifi (2016) found that the debt-to-equity ratio in the first and third years significantly affects the timeliness of corporate financial reporting.

\section{$\mathrm{H}_{3}$ : Partially Debt to Equity Ratio has a significant effect on the Timelines Financial Report on banking companies listed on the Indonesia Stock Exchange for the period 2014-2019.}

\subsection{Firm Size}

Company size can be assessed from several aspects (Zandi, 2019) measuring the size of the company in total asset value. Abernathy et al. (2018) measured company size using market value. The greater the amount of capital that is invested, the more sales, the more circulation of money and the greater the market capital, the greater it is known in society (Zandi, 2019). Company Size $($ Size $)=$ Ln (total asset value). Large companies are more in the spotlight by the public, therefore large companies tend to maintain the company's image in the eyes of the public by submitting their financial reports in a timely manner. Research on company size on timeliness was carried out by Nelson et al. (2019), in their research empirical evidence was found that it significantly affects the timeliness of corporate financial reporting.

\section{$\mathrm{H}_{4}$ : Partially Firm Size has a significant effect on the Timelines Financial Report on banking companies listed on the Indonesia Stock Exchange for the period 2014-2019.}

\section{Method}

\subsection{Sample}

The research sample was selected using a purposive sampling approach, meaning that the sample used in this study was a sample that met certain criteria. The purpose of using this method is to obtain a representative sample. The criteria used in sampling are as follows: Banking companies listed on the Indonesian Stock Exchange consecutively from 2014 to 2019, publish financial reports and annual reports from 2014 to 2019, are companies engaged in the sector of banking, displaying data and information used to analyze the factors that affect the timeliness of financial reporting from 2014 to 2019. Based on the sampling criteria, 43 banking companies listed on the Indonesia Stock Exchange were obtained as research samples which are presented in Table 1.

\section{Table 1}

The population of the company under study

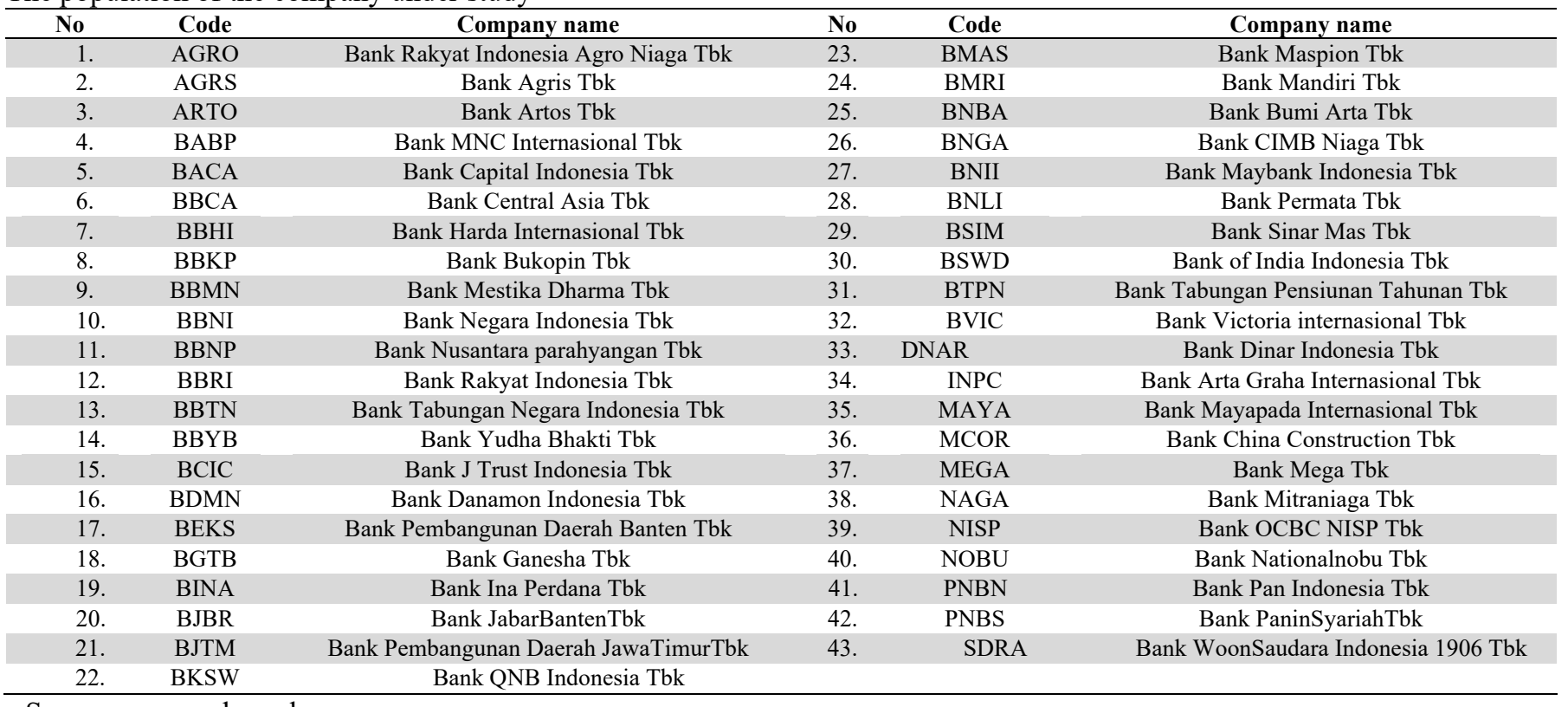

Source: www.sahamoke.com

Table 1 shows the banking companies listed on the Indonesia Stock Exchange (IDX). The number of banking companies listed on the IDX is 43 companies, however, only 26 companies publish their financial reports annually. In this study, researchers used 
10 companies as a sample by using the variable company size, liquidity, debt to equity ratio and Firm Size as factors that affect the timeliness of financial reporting. The research sample was selected using a purposive sampling approach, meaning that the sample used in this study was a sample that met certain criteria. The purpose of using this method is to obtain a representative sample. The criteria used in sampling are as follows: Banking companies listed on the IDX consecutively from 2014 to 2019,Publish financial reports and annual reports from 2014 to 2019,Is a company engaged in the banking sector. Displays the data and information used to analyze the factors that affect the timeliness of financial reporting in the 2014 to 2019 period. Based on the sampling criteria, 10 banking companies listed on the Indonesia Stock Exchange were obtained as research samples which are presented in Table 2 as follows:

Table 2

The sample of companies studied

\begin{tabular}{ccc}
\hline No & Code & Company Name \\
\hline 1 & AGRO & Bank Rakyat Indonesi Agro NiagaTbk \\
2 & BABP & Bank MNC InternasionalTbk \\
3 & BACA & Bank Capital IndonesiaTbk \\
4 & BBKP & Bank BukopinTbk \\
5 & BNBA & Bank BumiArtaTbk \\
6 & BSWD & Bank of India IndonesiaTbk \\
7 & BTPN & Bank Tabungan PensiunanTahunanTbk \\
8 & BVIC & Bank Victoria InternasionalTbk \\
9 & BDMN & Bank Danamon Indonesia Tbk \\
10 & BNII & Bank Maybank Indonesia Tbk \\
\hline
\end{tabular}

\subsection{Measure}

The operational definition of a variable is the definition of a variable (which is expressed in the concept definition), operationally, in practice, in real terms within the scope of the research object / object under study. The variables used in this study are the independent variables and the dependent variable. The independent variable is the variable that affects the dependent variable, either positively or negatively. In this study, the independent variables are liquidity, Debt to Equity Ratio (DER) and Firm Size.

a. Liquidity is a variable used to measure how much the company's ability to pay short-term debt of a company is used as a sample. Liquidity can be based on the total value of Current Asset against Current Liability. The greater the value of these items, the greater the company's liquidity. In this research, company size is proxied using Ln total assets. Measured by a ratio scale.

b. Debt to Equity Ratio (DER) is used to measure the level of leverage (use of debt) against the total shareholder's equity owned by the company. Debt to Equity Ratio (DER) can also provide an overview of the capital structure owned by a company, so that it can be seen that the risk level of a debt is uncollectible measured by a ratio scale.

c. Firm Size is a variable used to measure how big or small a company is used as a sample. The size of the company can be based on the total asset value, total sales, market capitalization, the number of workers. The greater the value of these items, the greater the size of the company. In this research, company size is proxied using Ln total assets. The use of natural log $(\mathrm{Ln})$ in this study is to reduce excessive fluctuation of data. If the total asset value is directly used, the variable value will be very large. By using the natural log, this very large value will be simplified without changing the proportion of the original value that was actually measured by the ratio scale. Firm Size $=$ Ln (total Assets).

Dependent variable is a variable that is the main concern of researchers, in other words, it is the main variable that becomes a factor in investment (Sekaran, 2007: 116). In this study the dependent variable is timeliness. Timeliness of financial reporting is the time span to announce audited annual financial reports to the public. From the closing date of the book to the closing date of the company's book (31 December) to the date of submission to Adelopo et al. (2018) measured on a nominal scale.

Dependent variable is a variable that is the main concern of researchers, in other words, it is the main variable that becomes a factor in investment (Budi \& Mulyana, 2017). In this study the dependent variable is timeliness. Timeliness of financial reporting is the time span to announce audited annual financial reports to the public. From the closing date of the book to the closing date of the company's book (31 December) to the date of submission to Abernathy et al. (2018) measured on a nominal scale.

Dependent variable is a variable that is the main concern of researchers, in other words, it is the main variable that becomes a factor in investment ( Du \& Wu, 2018). In this study the dependent variable is timeliness. Timeliness of financial reporting is the time span to announce audited annual financial reports to the public. From the closing date of the book to the closing date of the company's book (31 December) to the date of submission to Al-Juaidi and Al-Afifi (2016) measured on a nominal scale. 
Dependent variable is a variable that is the main concern of researchers, in other words, it is the main variable that becomes a factor in investment (Johnston \& Zhang, 2018). In this study the dependent variable is timeliness. Timeliness of financial reporting is the time span to announce audited annual financial reports to the public. From the closing date of the book to the closing date of the company's book (31 December) to the date of submission to Baye and Prince (2016) measured on a nominal scale.

Dependent variable is a variable that is the main concern of researchers, in other words, it is the main variable that becomes a factor in investment (Chukwu \& Nwabochi, 2019). In this study the dependent variable is timeliness. Timeliness of financial reporting is the time span to announce audited annual financial reports to the public. From the closing date of the book to the closing date of the company's book (31 December) to the date of submission to measure on a nominal scale (Nelson et al., 2018).

Dependent variable is a variable that is the main concern of researchers, in other words, it is the main variable that becomes a factor in investment (Tan et al., 2017). In this study the dependent variable is timeliness. Timeliness of financial reporting is the time span to announce audited annual financial reports to the public. From the closing date of the book to the closing date of the company's book (31 December) to the date of submission to Murti (2017z) measured on a nominal scale. Dependent variable is a variable that is the main concern of researchers, in other words, it is the main variable that becomes a factor in investment (Kemal, 2019). In this study, the dependent variable is timeliness. Timeliness of financial reporting is the time span to announce audited annual financial reports to the public. From the closing date of the book to the closing date of the company's book (31 December) to the date of submission Murti (2017) measured on a nominal scale. Dependent variable is a variable that is the main concern of researchers, in other words, it is the main variable that becomes a factor in investment (Baye \& Prince, 2016). In this study, the dependent variable is timeliness. Timeliness of financial reporting is the time span to announce audited annual financial reports to the public. From the closing date of the book to the closing date of the company's book (31 December) to the date of submission to measure on a nominal scale.

\subsection{Data Analysis}

The method used in this research to collect the required data is the documentation method. The documentation method is to look for data about things or variables in the form of notes, transcripts, books, newspapers, magazines, meeting minutes, agendas, and so on (Murti, 2017a,b). In this study, researchers took data regarding the annual financial statements of banking companies listed on the Indonesia Stock Exchange (BEI) during the 2014-2019 period by processing data using Eviews version 9. Descriptive statistics provide a description or descriptive of data from the average (mean), standard deviation, variant, maximum, minimum, sum, range, kurtosis and Skewness (slope distribution). Descriptive statistics describe data into information that is clearer and easier to understand. Besides that, descriptive statistics are used to develop the profile of the companies being sampled. To find out whether the regression model really shows a significant and representative relationship, the model must meet the classic regression assumptions. The classical assumption tests carried out were data normality test, multicollinearity test, heteroscedasticity test, and auto correlation test. The general form of the equation structure for the panel data analysis model is as follows: $Y=\alpha+\beta_{1} X_{1}+\beta_{2} X_{2}+\beta_{3} X_{3}+e, Y=$ Timeliness of Financial Reporting, $\alpha=$ Constant, $\beta_{1}, \ldots, \beta_{3}=$ Regression Coefficients, $X_{1}=$ Firm Size, $X_{2}=$ DER, $X_{3}=$ liquidity, e $=$ Error judging from the parameter estimation method, panel data analysis models can be grouped into models without individual effects (common effect) and models with individual effects (fixed effect and random effect). Common effects model or Pooled Regression Model is an estimation method that combines (pooled) all time serries and cross section data and uses the OLS (Ordinary Leas Square) approach to estimate the parameters. As a result, this model has the same $\alpha$ intercept and $\beta$ slop for each individual, so that the time and individual differences will not be visible. The general form for the Ordinary Least Square (OLS) model is: $Y=\alpha+\beta_{1} X_{1}+\beta_{2} X_{2}+\beta_{3} X_{3}+e$. The Random Effect model is an estimation model with different interceptions for each individual by taking into account the disturbance of the cross section and time series. because of that, the random effects model is often called an error component model. The appropriate method used to estimate the Random Effect is the General Lease Square (GLS) as the estimator, because it can increase the efficiency of the Lease Square estimation. The Random Effect Model is often called the Error Component Model (ECM). The decision to use the random effects model is determined using this specification. This will provide an assessment using the Chi Square Statistic so that the decision to choose the model can be determined statistically, namely by using the Chow Test and the Hausman Test.

\section{Result}

Table 3

Descriptive Statistics Test Results

\begin{tabular}{|c|c|c|c|c|c|}
\hline Variable & $\mathbf{n}$ & Minimum & Maximum & Mean & Standard deviation \\
\hline Time Lines (Y) & 60 & 16 & 89 & 68.25 & 17.28 \\
\hline Liquidity $\left(\mathrm{X}_{1}\right)$ & 60 & 15.36 & 29.59 & 21.23 & 4.60 \\
\hline $\operatorname{DER}\left(\mathrm{X}_{2}\right)$ & 60 & 0.007 & 12.15 & 6.61 & 3.15 \\
\hline Firm Size $\left(X_{3}\right)$ & 60 & 0.005 & 0.55 & 0.19 & 0.17 \\
\hline
\end{tabular}

Source: secondary data that has been processed 
Descriptive statistics are used to describe the variables in the study which will provide an overview of each research variable. Wayu Murti (2017). Descriptive Analysis of the Timeliness of Financial Reporting (Y). Based on Table $3 \mathrm{~s}$, the timeliness shows a minimum value of 16 days and a maximum value of 89 days. The mean punctuality of time is 68 days with a standard deviation of 17. 28. The average timeliness of company reporting is still below 90 days, which is the time limit for submission of financial statements set by BAPEPAM. The fastest time to report its financial statements is the company Bank Danamon Tbk (BDMN). The company reported its financial statements within 16 days occurred in 2019, while the longest reporting was 89 days owned by the company Bank Victoria International Tbk in 2014. Based on the results of descriptive analysis of company size variables can be seen in Table 2. Banking index issuers listed on the Indonesia Stock Exchange during the period 2014 to 2019 , show that company size has a minimum value of 15.36 and a maximum value of 29.59 with an average of 21.23 and a standard deviation of 4.60. Having the minimum assets in this study is owned by Bank Capital Indonesia Tbk in 2014, while the companies that have the maximum assets in this study are owned by Bank Bumi Arta Tbk in 2019.Debt to Equity Ratio is a measure of the level of use of debt to the total shareholder equity owned by the company or also a description of the capital structure owned by the company. Based on table 2, DER has a minimum value range of 0.007 and a maximum value of 12.15 , with an average of 6.61 and a standard deviation of 3.15. The company with the lowest DER was Bank Capital Indonesia Tbk in 2014 while the largest was Bank Bukopin in 2015. Firm Size is the number of percentages of company size that are owned by the public. Firm Size has a minimum value range of 0.0005 , a maximum value of 0.55 , with an average value of 0.19 and a standard deviation of 0.17 . Companies that have a minimum value are Bank of India Indonesia Tbk in 2014 and 2015, while companies with maximum value are Bank MNC International Tbk in 2014.Liquidity, Firm Size, Debt to Equity Ratio simultaneously and partially have a significant effect on the Timelines Financial Report on banking companies listed on the Indonesia Stock Exchange for the period of 2014-2019.

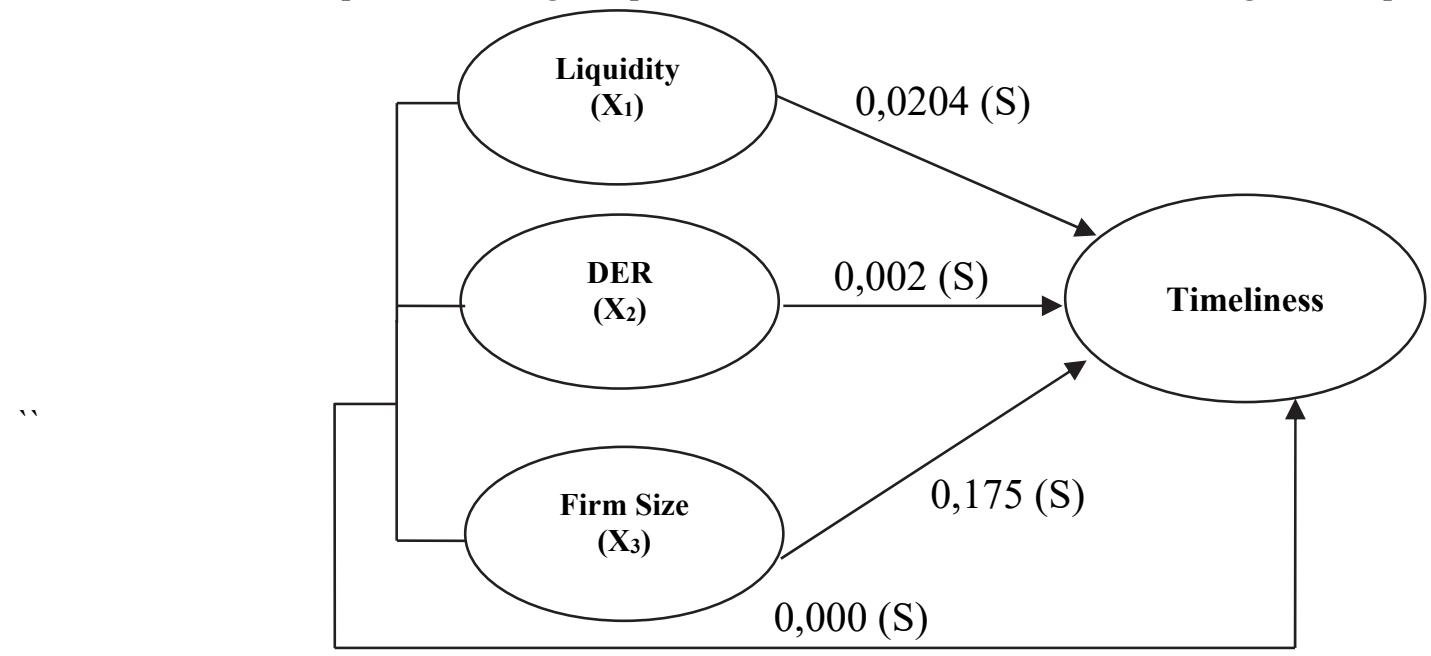

Information:

Fig. 1. Path Diagram

$\mathrm{S}$ : Significant

NS: Not Significant

The research above shows that simultaneously and partially it has an effect on liquidity, debt to equity ratio, firm size to timelines, research results and interpretation after calculating with Eviews 9 on the analyzed data resulting in a classic assumption test consisting of normality test, Heterocedacity test, the autocorrelation test fulfils the research eligibility requirements.

\section{Discussion}

Research using data analysis can determine that panel data analysis can determine the best final panel data result, so the model selection is done through calculations, the selection can be a model without individual effects (common effect) or a model with individual effects (fixed effect and random effect). Selection can be made manually using the Chow/F test. Hypothesis: Ho: Common Effect or Pooled OLS ModelHi: Model with Individual Effects. To determine the regression model, it is necessary to perform the Chow test and the Hausman test, as follows:

\subsection{Panel Data Estimate Model}

Modeling in using panel data regression techniques can use some alternative approaches for processing methods. These approaches are: Common Effect Mode Method (The Pooled OLS Methods) and Fixed Effect Model (FEM) Method. 
Tabel 4

Model Fixed Effect

\begin{tabular}{|c|c|c|c|c|}
\hline Variable & Coefficient & Std. Error & t-Statistic & Prob. \\
\hline $\mathrm{C}$ & 18.97611 & 1.025559 & 20.45334 & 0.0000 \\
\hline $1 \mathrm{Q} ?$ & 0.125009 & 0.052061 & -2.401188 & 0.0204 \\
\hline DER? & 0.29676 & 1.543502 & -4.079527 & 0.0002 \\
\hline FM? & 0.90337 & 0.013688 & 2.462016 & 0.0175 \\
\hline \multicolumn{5}{|c|}{ Effects Specification } \\
\hline \multicolumn{5}{|c|}{ Cross-section fixed (dummy variables) } \\
\hline R-squared & 0.86792 & Mean dependent var & & 21.2375 \\
\hline Adjusted R-squared & 0.859729 & S.D. dependent var & & 4.596191 \\
\hline S.E. of regression & 0.922347 & Akaike info criterion & & 2.865345 \\
\hline Sum squared resid & 39.984 & Schwarz criterion & & 3.31912 \\
\hline Log likelihood & 72.96036 & Hannan-Quinn criter. & & 3.042841 \\
\hline F-statistic & 118.1729 & Durbin-Watson stat & & 2.13187 \\
\hline Prob(F-statistic) & 0.0000 & & & \\
\hline
\end{tabular}

Based on Table 4, it can be seen that the determination can be seen in the Chow or Hausman Test.

\subsection{Chow Test (Common Effect Model Vs Fixed Effect Model Method)}

Through statistical testing, the selection between the two models mentioned above can be resolved by testing the F-Statistic / Chow Test as follows: If the probability value of Cross-section $\mathrm{F}$ and Cross-section Chi-square is greater than 0.05 , the regression model chosen is the Common Effect Model, and does not need to be continued with the Hausman Test. If the probability value of Cross-section F and Cross Section Chi-square is less than 0.05, the regression model chosen is Fixed Effect Model, followed by the Hausman Test. The following is the F-Statistic test or Chow Test, the following results are obtained:

Table 5

Chow Test

\begin{tabular}{llll}
\hline Effects Test & Statistic & d.f. & Prob. \\
\hline Cross-section F & 62.920063 & $(9,47)$ & 0.0000 \\
Cross-section Chi-square & 154.120496 & 9 & 0.0000 \\
\hline
\end{tabular}

Based on the test results above, the method chosen is the Fixed Effect Model method. The test results can be proven by the probability value of Cross-section F and Cross-section Chi square 0.0000 less than 0.05 , so the regression model chosen is the Fixed Effect Model. In accordance with the testing provisions mentioned above, it is necessary to continue with the Hausman test.

\subsection{Hausman Test (Fixed Effect Model Vs Random Effect Model)}

The Hausman Test aims to compare the Fixed Effect Model method and the Random Effect Model method. The results of the test using the Hausman Test are to find out which method should be chosen. The provisions for the Hausman Test are as follows: If the probability value of a random cross-section is greater than 0.05 , the regression model chosen is the Random Effect Model. If the probability value of a random cross-section is less than 0.05 , the regression model chosen is the Fixed Effect Model. The following is the output of the test using the Hausman Test as follows:

Table 6

Hausman Testing

\begin{tabular}{llll}
\hline Test Summary & Chi-Sq. Statistic & Chi-Sq. d.f. & Prob. \\
\hline Cross-section random & 18.890819 & 3 & 0.0003 \\
\hline
\end{tabular}

Based on the test results above, the method chosen is the Fixed Effect Model method. The test results can be proven by the probability value of a random cross-section of 0.0003 is smaller than 0.05 . Thus, it can be concluded that the regression model chosen is the Fixed Effect Model. The F-statistic test is used to determine the relationship between the independent variables jointly affecting the dependent variable. According to Wahyu Murti (2017) "If the value of Prob $\mathrm{F}<0.05$ means that the independent variables jointly affect the dependent variable". Based on Table 6 , the calculation results obtained are the probability significance value of $0.000000<0.05$ which means positive and significant, indicating that the variables of liquidity (X1), DER (X2), and Firm Size (X3) simultaneously have a significant influence on Timeliness Financial Report. The $t$ test aims to determine the effect of the independent variables consisting of liquidity (X1), DER (X2), and Firm Size (X3) variables which partially have a significant effect on the Timelines Financial Report, indicated by a probability smaller than $\alpha<0.05$. 
The coefficient of determination is used to determine the amount of contribution between independent variables to the increase or decrease in the dependent variable. Based on Table 4, the value of $\mathrm{R}^{2}$ is 0.859729 , which shows the contribution of the influence of Liquidity, Debt To Equity Ratio, and Firm Size on Time liness Financial Report. While the remaining 14.01\% is the influence of other factors outside the research. Linear regression equation $=18.97611+0.125009 \mathrm{LQ}+6.296760 \mathrm{DER}+0.0033700 \mathrm{FS}$.

Hypothesis 1: Liquidity, DER, Company Size simultaneously has a significant effect on the Timeliness of Financial Reporting in banking companies listed on the Indonesia Stock Exchange for the period 2014-2019 based on an f-statistic value of $0.000000<0.05$. The coefficient of determination (Adjusted $\mathrm{R}^{2}$ ) is obtained a result of 0.859 or $85.9 \%$. This shows that the Punctuality of Financial Reporting can be explained by the variables of Liquidity, DER and Company Size of $8.59 \%$ while the remaining $11.41 \%$ is influenced by other factors outside the research.

Hypothesis 2: Liquidity partially has a positive and significant effect on Timeliness of Financial Reporting. This is based on the probability value of 0.0204 which is smaller than 0.05 , meaning that the greater the liquidity of a banking company, the faster the timeliness will be.

Hypothesis 3: DER partially has a positive and significant effect on the timeliness of financial reporting. This is based on the probability value of 0.0204 which is smaller than 0.05 , meaning that the greater the company's DER, the faster the timeliness will be.

Hypothesis 4: Company Size partially has a positive and significant effect on the Timeliness of Financial Reporting. This is based on the probability value of 0.0175 which is smaller than 0.05 , meaning that the bigger the company size, the faster the timeliness.

\subsection{Contribution for theory and practice}

Contribution to the theory that the timeliness of financial reports on the Indonesian Stock Exchange for banking companies that go public is strongly influenced by liquidity Debt Equity Ratio and Company Size. There is a simultaneous significant positive relationship between liquidity, Deb Equity Ratio and company size on reporting accuracy finance for banking companies going public in Indonesia. Contribution for practitioners to work professionally and conduct periodic evaluations of the performance of each division of the company in order to control the dominant factors that affect the length of time punctuality, such as Liquidity, Deb Equity Ratio and company size.

\subsection{Limitations and future research}

In this study, the timeliness of reporting financial information is very much needed by users of financial statement information. This is because financial reports are an important element needed by information users to make investment and credit decisions. The problem of timeliness in financial reporting is increasingly important in line with the progress of the business world. When companies postpone financial reporting to the public, the information can no longer be used for research.

In future research, other factors that are thought to affect the timeliness of reporting include public ownership, Return On Investments, Return On Assets, Earning After Tax and solvency. Apart from being independent variables using other variables besides being studied, it is also necessary to add research objects banks that have good financial performance and have timeliness in reporting finances to the Jakarta Stock Exchange.

\section{Conclusion}

Liquidity, DER and Firm Sizes simultaneously and partially have significant effects on the Timeliness of Financial Reporting in banking companies listed on the Indonesia Stock Exchange. The coefficient of determination (Adjusted $\mathrm{R}^{2}$ ) was 0.859729 or 85.97\%. This shows that the Timeliness Financial Report can be explained by the liquidity variable, DER and Firm Size of 85.97\%, while the remaining $14.01 \%$ is influenced by other factors outside of research. It is recommended that the company should continue to work professionally and conduct periodic evaluations of the performance of each division of the company in order to control the dominant factors that affect the duration of the Timeliness Financial Report such as: Liquidity, Debt to Equity Ratio, and Firm Size. 


\section{Acknowledgment}

The authors would like to thank to the Indonesia Stock Exchange for providing data for research as well as the Indonesian Central Bureau of Statistics for supporting sports data.

\section{References}

Adelopo, I., Lloydking, R., \& Tauringana, V. (2018). Determinants of bank profitability before, during, and after the financial crisis. International Journal of Managerial Finance, 14(4), 378-398. Available at: https://doi.org/10.1108/ijmf-07- 2017-0148

Abernathy, J. L., Kubick, T. R., \& Masli, A. (2018). Evidence on the relation between managerial ability and financial reporting timeliness. International Journal of Auditing, 22(2), 185-196.

Al-Juaidi, O., \& Al-Afifi, A. A. (2016). The Factors Affecting Timeliness of Corporate Financial Reporting: Empirical Evidence from the Palestinian and Amman Stock Exchange. International Journal of Management Sciences and Business Research, $5(10)$.

Arowoshegbe, A. O., Uniamikogbo, E., \& Adeusi, A. S. (2017). Factors affecting timeliness of an audit report in Nigeria. Funai Journal of Accounting, Business and Finance, 1(1), 26-38.

Budi, I. W., \& Mulyana, B. (2017). The effect of internal and external factors of companies on profitability and its implications on stock price index of state-owned banks. Economics, 5(2), 58-71.

Baye, M., \& Prince, J. (2016). Managerial economics \& business strategy. $9^{\text {th }}$ Edn., New York: McGraw-Hill Irwin.

Chakroun, R., \& Hussainey, K. (2013). Disclosure Quality in Tunisian Annual Reports. Paper presented at the Paper presented at the Critical Studies in Accounting, Economics and Finance (CSAF) Conference, Abu Dhabi, UAE.

Chukwu, G. J., \& Nwabochi, N. (2019). Audit Committee Characteristics and Timeliness of Corporate Financial Reporting in the Nigerian Insurance Industry. International Journal of Managerial Studies and Research, 7(4), 86-95.

Creswell, J. W. (2014). Research design: Qualitative, Quantitative, and Mixed Methods Approach. 4 ed. London, UK: SAGE Publications, Inc.

Du, H., \& Wu, K. (2018). XBRL mandate and timeliness of financial reporting: Do XBRL filings take longer?. Journal of Emerging Technologies in Accounting, 15(1), 57-75.

Kemal, M. (2019). Determinants of the timeliness of financial reporting: Empirical evidence from Turkey. Hacettepe University Journal of Economics and Administrative Sciences, 37(2), 365-386.

Krishnamoorthy, G., Wright, A., \& Cohen, J. (2002). Audit committee effectiveness and financial reporting quality: Implications for auditor independence. Australian Accounting Review, 12(28), 3-13.

Johnston, J. A., \& Zhang, J. H. (2018). Information technology investment and the timeliness of financial reports. Journal of Emerging Technologies in Accounting, 15(1), 77-101.

Murti, W. (2017a). The influence of crude oil price in biodesel and its implication on the production of palm oil:The case of Indonesia. European Research Studies Journal, 20(2), 568 -580.

Murti, W. (2017b). The influence of the contagion effect and the spillover effect of global financial market on the stock index: The case of Indonesia. European Research Studies Journal, 20(4B), 99-111.

Nelson, S., Ahmad, M., \& Mohamed, H. (2019). Relationship between the Industry Specialist Auditors and Financial Reporting Timeliness under MFRS. Pertanika Journal of Social Sciences \& Humanities, 27(1).

Pinto, P., \& Joseph, N. R. (2017). Capital structure and financial performance of banks. International Journal of Applied Business and Economic Research, 15(23), 303-312.

Sufiyati, S. (2017). The Impact of Corporate Attributes on the Timeliness of Financial Reporting in Indonesia Stock Exchange. International Journal of Economic Perspectives, 11(1), 1720-1730.

Tan, Y., Floros, C., \& Anchor, J. (2017). The profitability of Chinese banks: impacts of risk, competition and efficiency. Review of Accounting and Finance, 16(1), 86-105.

Viet, H. T., Hung, D. N., \& Thanh, N. T. (2018). The study of factors affecting the timeliness of financial reports: The experiments on listed companies in Vietnam. Asian Economic and Financial Review, 8(2), 294-307.

Zandi, G. (2019). Financial statements timeliness: The case of Malaysian listed industrial product companies. Asian Academy of Management Journal, 24(2), 127-141, 


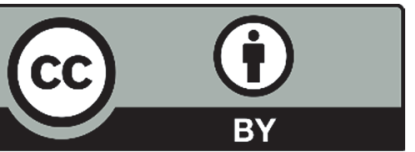

(C) 2021 by the authors; licensee Growing Science, Canada. This is an open access article distributed under the terms and conditions of the Creative Commons Attribution (CC-BY) license (http://creativecommons.org/licenses/by/4.0/). 